\title{
Pengembangan model manajemen bimbingan karir menggunakan aplikasi Edmodo
}

\author{
Wahyu Widia Astuti *, Yari Dwikurnaningsih \\ Universitas Kristen Satya Wacana \\ J1. Diponegoro No. 52-60, Kota Salatiga, Jawa Tengah 50711, Indonesia. \\ * Corresponding Author. Email: wahyuwidia93@gmail.com
}

\section{ARTICLE INFO}

\section{Article History}

Received:

20 December 2020;

Revised:

27 April 2021;

Accepted:

3 May 2021

Available online:

3 May 2021

\section{Keywords}

manajemen;

bimbingan karir;

edmodo;

model.

management;

career guidance;

edmodo;

model.

\begin{abstract}
Penelitian ini bertujuan menghasilkan produk berupa model manajemen bimbingan karir menggunakan aplikasi Edmodo yang memenuhi lima aspek: aspek tampilan, akses, interaksi, desain materi layanan, dan kontrol. Pendekatan penelitian menggunakan metode penelitian Research \& Development (R\&D) melalui tiga langkah pe-ngembangan, yaitu tahap studi pendahuluan, tahap desain dan pengembangan model, tahap pengujian produk dan publikasi. Pengembangan produk mengacu pada model pengembangan ADDIE yang meliputi tahap Analysis, Design, Development, Implementation and Evaluation. Data dikumpulkan melalui observasi dan wawancara. Uji ahli dan uji lapangan terbatas dianalisis dengan teknik deskriptif kuantitatif melalui penghitungan rerata dan persentase serta pengkategorian. Pengembangan model diperoleh dengan prinsip-prinsip manajemen G.R.Terry, yaitu perencanaan, pengorganisasian, pelaksanaan, dan evaluasi. Hasil penelitian yaitu produk dengan nama MBK-MAE yang terdiri dari bagan model dan deskripsinya, materi bimbingan karir untuk SMK, panduan guru BK, panduan siswa, dan panduan untuk operator IT. Hasil uji validitas oleh ahli materi sebesar $88 \%$, ahli media sebesar $84 \%$ dan calon pengguna sebesar $83 \%$. Berdasarkan uji ahli dan uji lapangan terbatas tersebut, dapat disimpulkan bahwa produk berupa model manajemen bimbingan karir menggunakan aplikasi Edmodo masuk dalam kategori baik dan layak untuk digunakan.
\end{abstract}

This study aims to produce a product in the form of career guidance management model using the Edmodo application that fulfills five aspects, namely appearance, access, interaction, service material design, and control. The research approach uses the Research \& Development $(R \& D)$, the research method through three development steps, namely the preliminary study stage, the design and development stage of the model, the product testing phase and publication. Product development refers to the ADDIE development model which includes the Analysis, Design, Development, Implementation and Evaluation stages. The data collection method uses observation and interview. Expert tests and limited field tests were analyzed using quantitative descriptive techniques through the calculation of the mean and percentage and categorization. The development of the model is obtained by the principles of G.R.Terry management, namely planning, organizing, implementing, and evaluating. The results of this study are products with the name MBK-MAE consisting of a model charts and their descriptions, career guidance material for SMK, guidance counselors, student guides, and guidance for IT operators. The validity test result by material expert is $88 \%$, media expert is $84 \%$ and prospective users are $83 \%$. Based on the expert test and limited field test, it can be concluded that the product in the form of a career guidance management model using the Edmodo application is included in the good category and is suitable to be used.

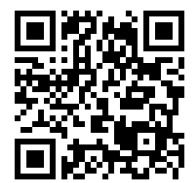

This is an open access article under the CC-BY-SA license.

How to cite:

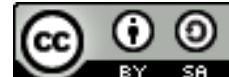

Astuti, W., \& Dwikurnaningsih, Y. (2021). Pengembangan model manajemen bimbingan karir menggunakan aplikasi Edmodo. Jurnal Akuntabilitas Manajemen Pendidikan, 9(1), 64-74. doi:https://doi.org/10.21831/jamp.v9i1.36761 


\section{PENDAHULUAN}

Keberadaan konselor dalam sistem Pendidikan nasional dinyatakan sebagai salah satu kualifikasi pendidik, sejajar dengan kualifikasi guru, dosen, pamong belajar, tutor, widyaiswara, fasilitator, serta instruktur (Undang-Undang Republik Indonesia Nomor 20 Tahun 2003 tentang Sistem Pendidikan Nasional Pasal 1 Ayat 6). Masing-masing kualifikasi pendidik, dalam hal ini termasuk konselor, memiliki keunikan konteks tugas dan ekspektasi kinerja. Konteks tugas konselor berada dalam kawasan pelayanan yang bertujuan mengembangkan potensi dan memandirikan konseli dalam pengambilan keputusan serta pilihan untuk mewujudkan kehidupan yang produktif, sejahtera, dan peduli pada kemaslahatan umum. Pelayanan dimaksud dalam hal ini adalah pelayanan bimbingan dan konseling.

Dalam melakukan tugasnya, seorang konselor sekolah dituntut untuk bekerja secara profesional dalam membimbing maupun dalam memberikan layanan kepada siswa. Selain itu, pemerintah mengeluarkan Peraturan Menteri Pendidikan Nasional Nomor 27 Tahun 2008 yang menjelaskan seorang konselor wajib memiliki kompetensi akademik dan profesional. Peran lain yang tak kalah penting bagi konselor adalah sebagai pengembang karir. Pentingnya pendidikan di sekolah sebagai landasan pengambilan keputusan siswa menegaskan pentingnya memberikan perhatian pada perkembangan karir siswa (Nursalim, 2015, p. 81).

Layanan bimbingan karir merupakan layanan khusus yang ada dalam layanan-layanan bimbingan dan konseling. Bimbingan karir menjadi salah satu bagian terpenting dalam pendidikan sekolah kejuruan. Ahli lain menyatakan bahwa bimbingan karir merupakan kegiatan memberi bantuan kepada siswa yang bertujuan agar siswa mampu menyesuaikan diri, memahami dunia kerja, dan menetapkan pilihan karir masa depannya, sebagai bentuk usaha membantu karir siswa agar siswa tidak kesulitan menentukan karirnya. Menurut Winkel dan Hastuti (2012, p. 623), bimbingan karir diartikan sebagai upaya memberikan pendidikan karir dan memfokuskannya pada pendampingan siswa agar perkembangaanya bisa maksimal dan terarah. Bimbingan karir yang disebut juga sebagai bimbingan jabatan adalah bentuk upaya pendidikan karir atau pendidikan jabatan, dan secara bersamaan fokus pada pendampingan perkembangan karir remaja. Dari beberapa pengertian tersebut, maka diperoleh kesimpulan bahwa bimbingan karir merupakan sebuah proses pemberian bantuan kepada konseli/siswa dari konselor supaya mampu mempersiapkan diri dan mampu menentukan karir untuk masa depannya.

Tingkat pendidikan Sekolah Menengah Kejuruan (SMK) memiliki tujuan khusus dalam pelaksanaan layanan bimbingan karir, yaitu mempersiapkan siswa/konseli untuk dapat menyesuaikan diri di masyarakat setelah tamat dari sekolah dan memiliki keterampilan bekerja yang dapat dipilih sesuai minat, kemampuan, dan kebutuhan yang ada di lingkungan masyarakatnya (Permatasari, 2019, p. 4). Hal ini sejalan dengan tujuan sekolah kejuruan, yaitu menghasilkan siswa/konseli yang mampu dan siap kerja di tengah-tengah masyarakat sesuai dengan kompetensi perilaku sikap dan kerja dalam bidang kejuruan yang ditempuhnya, sehingga siswa/konseli tersebut benar-benar mampu bekerja secara produktif sesuai harapan dan syarat yang diinginkan oleh dunia usaha dan dunia industri (DUDI), serta peka akan kebutuhan jasa/industri yang diperlukan oleh masyarakat saat ini (Permatasari, 2016, p. 270), sehingga, bimbingan karir merupagan bagian penting dalam mencapai tujuan dari SMK.

Pemerintah sering melakukan perubahan kurikulum untuk memperbaiki mutu pendidikan, termasuk memperbaiki kinerja konselor yang masih belum maksimal. Namun, dalam kurikulum terbaru, yaitu kurikulum 2013, beberapa sekolah mengalami kebingungan terkait jam masuk kelas bagi guru bimbingan dan konseling (BK). Melalui Peraturan Menteri Pendidikan Nasional Nomor 81A Tahun 2013, Menteri Pendidikan mengeluarkan peraturan mengenai jam masuk kelas bagi bimbingan dan konseling, di mana jam masuk bimbingan dan konseling ekuivalen dengan dua jam pembelajaran setiap kelas selama satu minggu. Namun, masih banyak sekolah kurang begitu memahami posisi bimbingan dan konseling pada kurikulum 2013. Beberapa sekolah tidak memberikan alokasi jam masuk kelas bagi bimbingan dan konseling karena mereka berasumsi bahwa layanan bimbingan dan konseling dapat diselenggarakan di luar jam pembelajaran.

Penelitian yang dilakukan oleh Irwan et al. (2017) dengan merancang sebuah software untuk bimbingan dan pengembangan karir berdasarkan pada metode certainty factor telah digunakan un- 
tuk membangun expert system atau sistem pakar, sehingga dapat membantu guru dan pembimbing dalam layanan bimbingan karir dan konseling untuk memecahkan permasalahan yang dihadapi siswa. Model manajemen layanan bimbingan karir menggunakan aplikasi Edmodo diharapkan dapat memberikan informasi karir, membantu siswa dalam berkonsultasi untuk mengambil keputusan pemilihan karir yang diminati siswa. Model ini dapat membantu guru memberikan layanan bombingan karir tanpa harus melakukan tatap muka dengan siswa. Untuk mewujudkan hal itu, pada penelitian ini peneliti mengambil judul penelitian "Pengembangan Model Manajemen Bimbingan Karir Menggunakan Aplikasi Edmodo".

\section{METODE}

Penelitian ini dilaksanakan dengan menggunakan pendekatan Reseach and Development $(R$ \& $D$ ). Penelitian ini merupakan penelitian pengembangan model manajemen bimbingan karir menggunakan aplikasi Edmodo. Penelitian dan pengembangan dilakukan dengan langkah-langkah tiga tahap penelitian pengembangan dari Sukmadinata (2012, p. 184) yang menyederhanakan model penelitian dan pengembangan Borg, Borg, dan Gall (2003). Langkah-langkah penelitian ini meliputi: (1) tahap studi pendahuluan, (2) tahap desain dan pengembangan model, dan (3) tahap pengujian produk dan publikasi. Validasi produk dilakukan oleh empat orang ahli yang terdiri atas dua orang ahli ahli teknologi informasi serta dua orang ahli bimbingan dan konseling.

Instrumen yang digunakan untuk menilai produk berupa kuesioner dengan lima skala penilaian dan dianalisis dengan kategori serta presentasi yang mengacu pada teori Arikunto (2011). Langkah selanjutnya yaitu uji lapangan terbatas yang dilakukan oleh praktisi (calon pengguna) produk, yaitu guru BK sebanyak tiga orang, serta delapan orang siswa dari SMK Diponegoro dan SMK Kristen BM Salatiga.

\section{HASIL DAN PEMBAHASAN}

Hasil pengembangan dari penelitian ini adalah model manajemen bimbingan karir menggunakan aplikasi Edmodo yang dilengkapi dengan buku panduan penggunaan aplikasi Edmodo untuk guru, siswa, dan operator IT serta materi bimbingan karir menggunakan Edmodo. Model bimbingan karir ini ditujukan kepada guru BK SMK untuk membantu siswa dalam pelaksanaan bimbingan karir menggunakan aplikasi Edmodo yang dilaksanakan secara berkelanjutan di kelas X, XI, XII. Produk ini dikembangkan dalam format bimbingan dengan delapan materi bimbingan karir untuk SMK yang dilaksanakan melalui media aplikasi Edmodo. Salah satu kelemahan yang terjadi pada kedua SMK ini adalah pembuatan program yang belum menjawab kebutuhan siswa dan terbatasnya waktu untuk guru BK memberikan layanan, serta kurangnya media yang digunakan untuk menyampaikan informasi karir. Namun, kelebihan proses bimbingan karir dari dua sekolah ini adalah adanya kerja sama tetap antara sekolah dan perusahaan yang bisa menjadi lapangan pekerjaan untuk siswa yang akan lulus sekolah. Untuk menjadi lebih maksimal lagi, maka peneliti menyusun perencanaan model manajemen bimbingan karir menggunakan aplikasi Edmodo. Gambar 1 menjelaskan model bimbingan karir menggunakan aplikasi Edmodo.

Tahap perencanaan di sekolah dilakukan dengan melakukan analisis kebutuhan terhadap bimbingan karir yang ada di SMK Diponegoro dan SMK Kristen BM Salatiga. Data analisis kebutuhan diambil menggunakan kuesioner yang dibagikan kepada siswa, sehingga dipereh hasil yang kemudian disusun menjadi Program BK Karir SMK. Tahap pengorganisasian merupakan cara untuk menempatkan orang berdasarkan kemampuan dan keahliannya dalam pekerjaan yang telah direncanakan. Pada tahap ini, akan ada beberapa orang yang terlibat dalam pelaksanaan bimbingan karir menggunakan aplikasi Edmodo. Pelaksanaan program adalah pelaksanaan tugas dan pekerjaan sesuai dengan pembagian kerja dan menggerakkan seluruh sumber daya yang ada agar pekerjaan yang telah dilakukan dapat berjalan sesuai dengan rencana. Tahap evaluasi adalah tahap dimana guru BK sebagai pelaksana melakukan kegiatan pengawasan dan penilaian seacra objektif atas efektifitas dan efisiensi pelaksanaan program, penggunaan sumber daya, dan waktu. Dalam layanan bimbingan karir, evaluasi dilakukan untuk mengukur ketercapaian tujuan layanan kepada siswa yang mengikuti proses layanan secara online. 


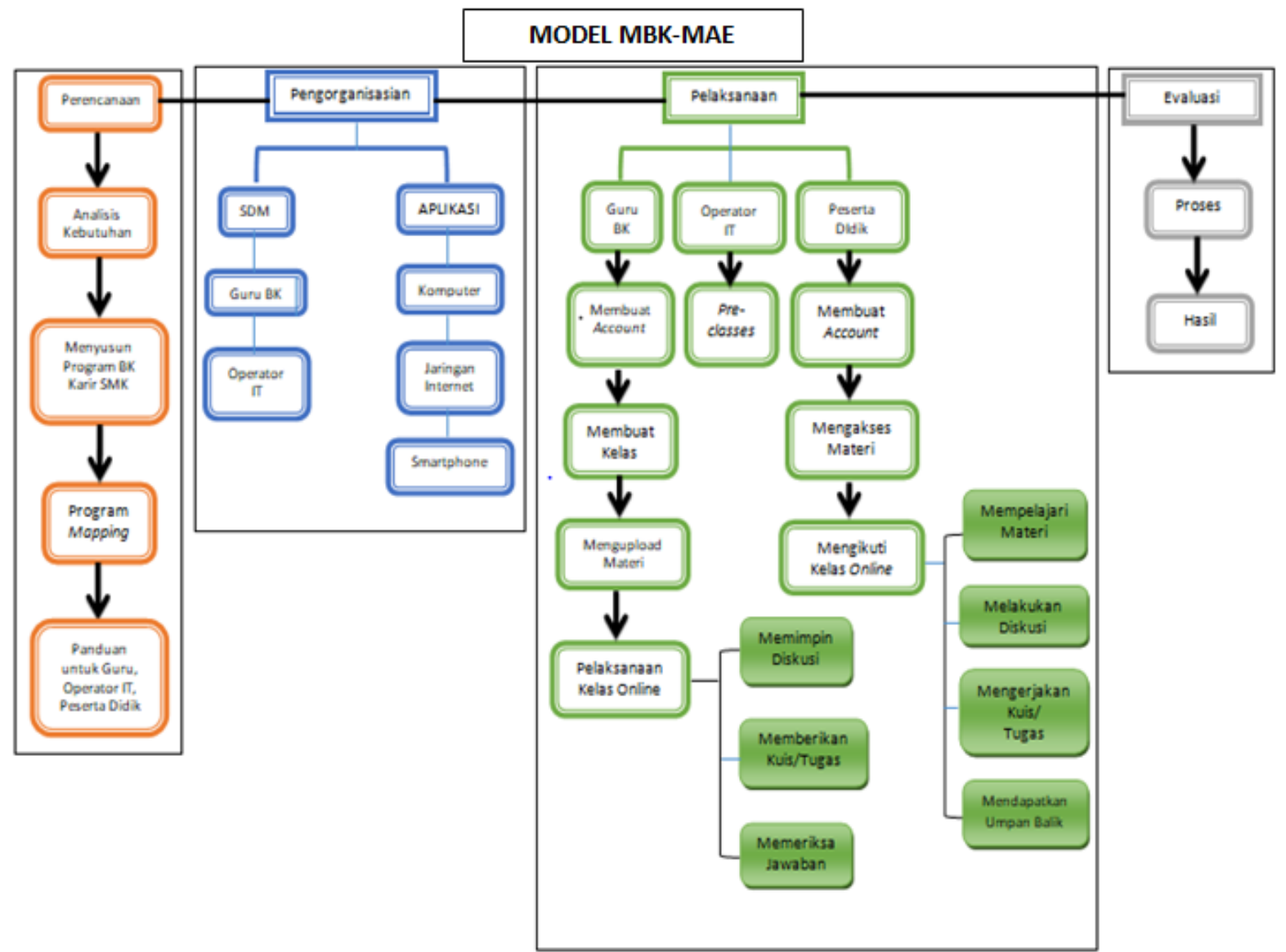

Gambar 1. Model Manajemen Bimbingan Karir Menggunkaan Aplikasi Edmodo

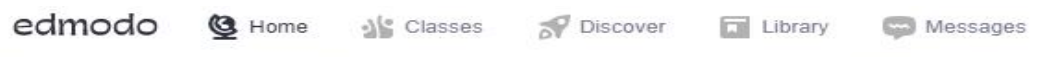

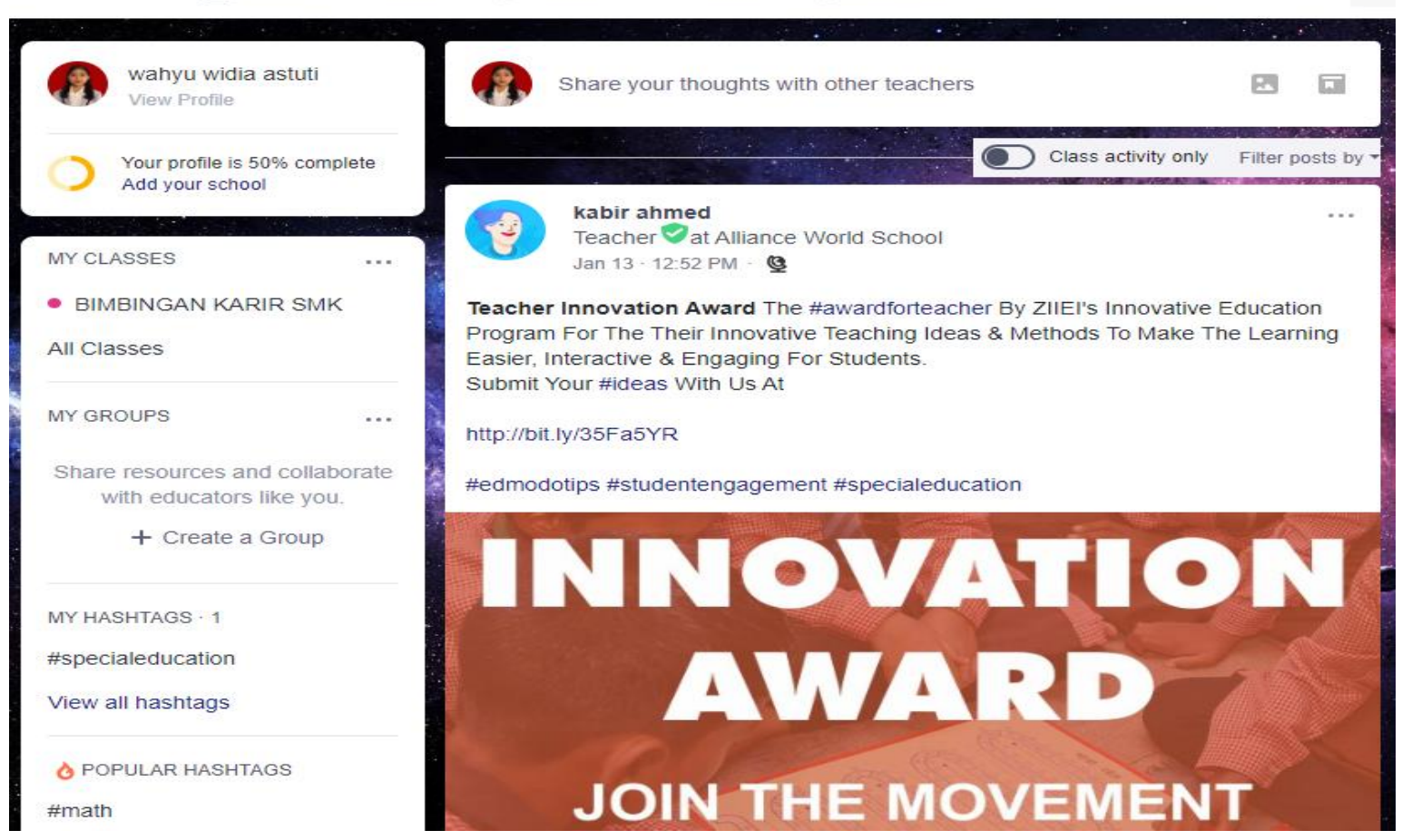

Gambar 2. Tampilan Classes di Aplikasi Edmodo 
Buku panduan penggunaan aplikasi Edmodo bagi guru BK, siswa, dan operator IT dilengkapi dengan gambar yang memperjelas panduan tertulis. Forum diskusi dalam lingkup kecil dilakukan dalam small group dan chatting untuk komunikasi baik dengan guru BK ataupun siswa lain secara pribadi. Adapun tampilan kelas, halaman materi, kuis, halaman small groups, dan juga halaman pesan pada aplikasi Edmodo ditunjukkan pada Gambar 2, Gambar 3, Gambar 4, Gambar 5, dan Gambar 6.

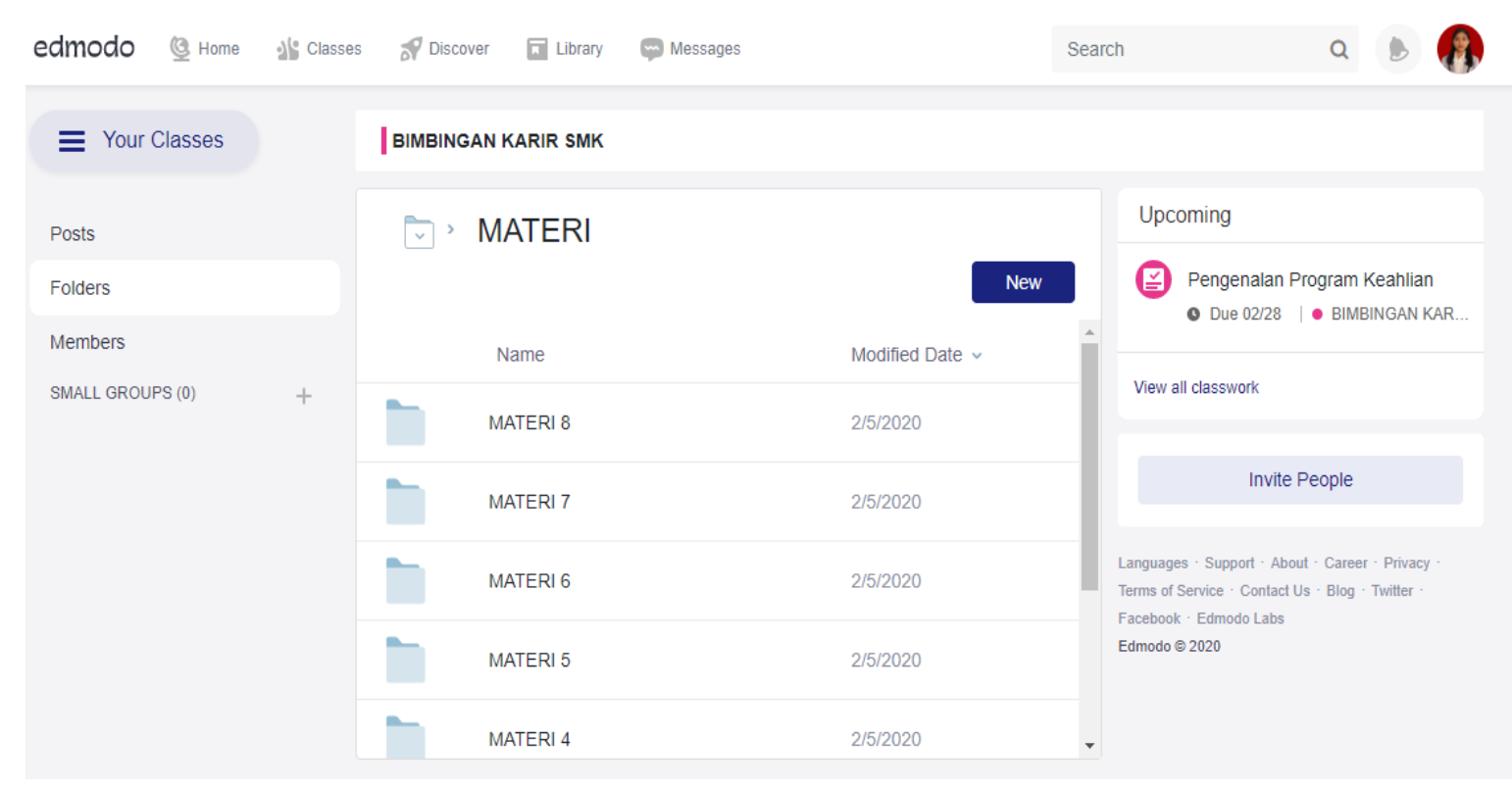

Gambar 3. Halaman Materi dan Contoh Materi

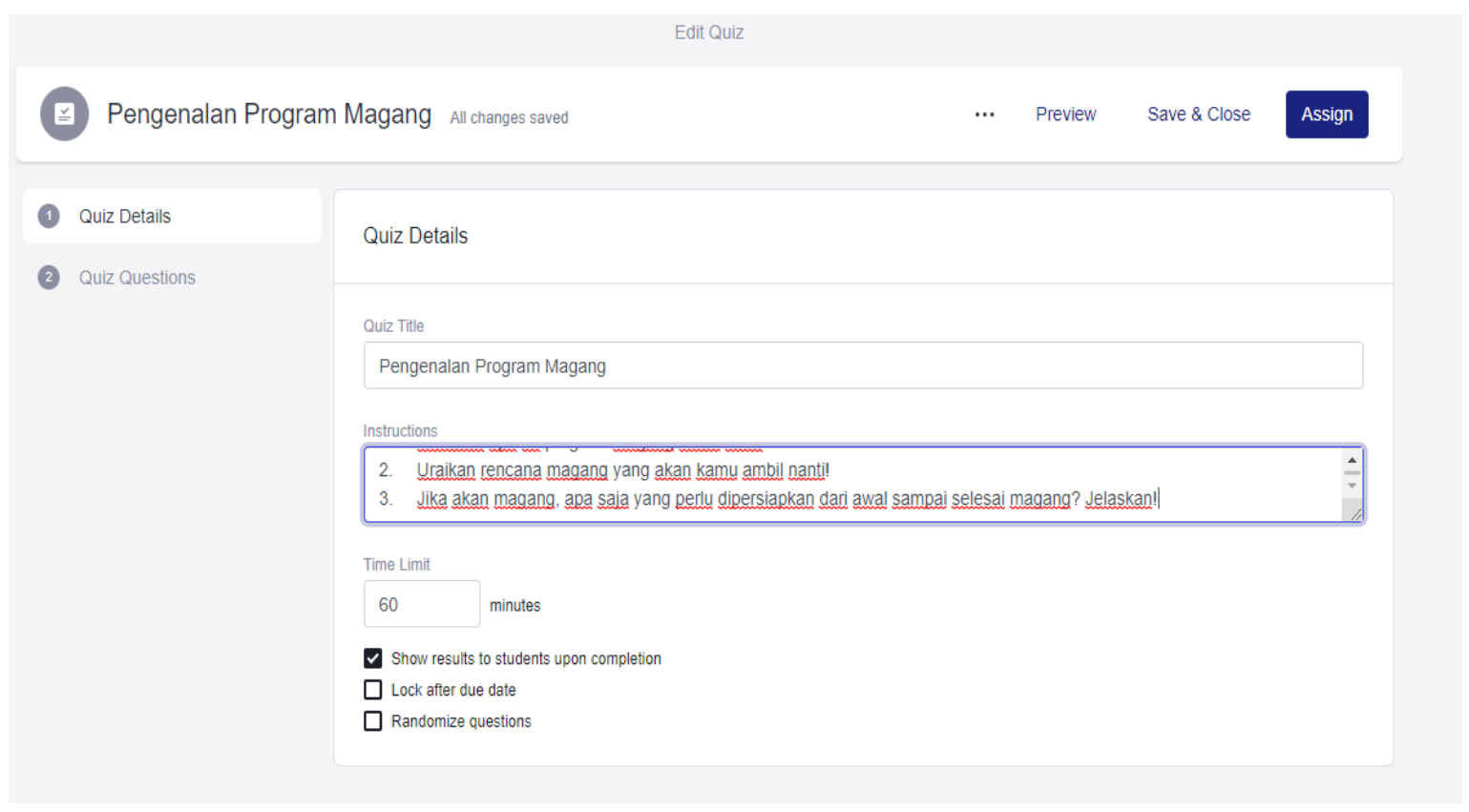

\section{Gambar 4. Halaman Quiz}

Setelah produk jadi dan siap digunakan, maka dilakukan uji validasi ahli information and technology (IT) dan materi berjumlah empat orang dan uji coba lapangan tebratas dengan delapan praktisi (calon pengguna), di mana hasilnya dapat dilihat pada Tabel 1, Tabel 2, dan Tabel 3. 


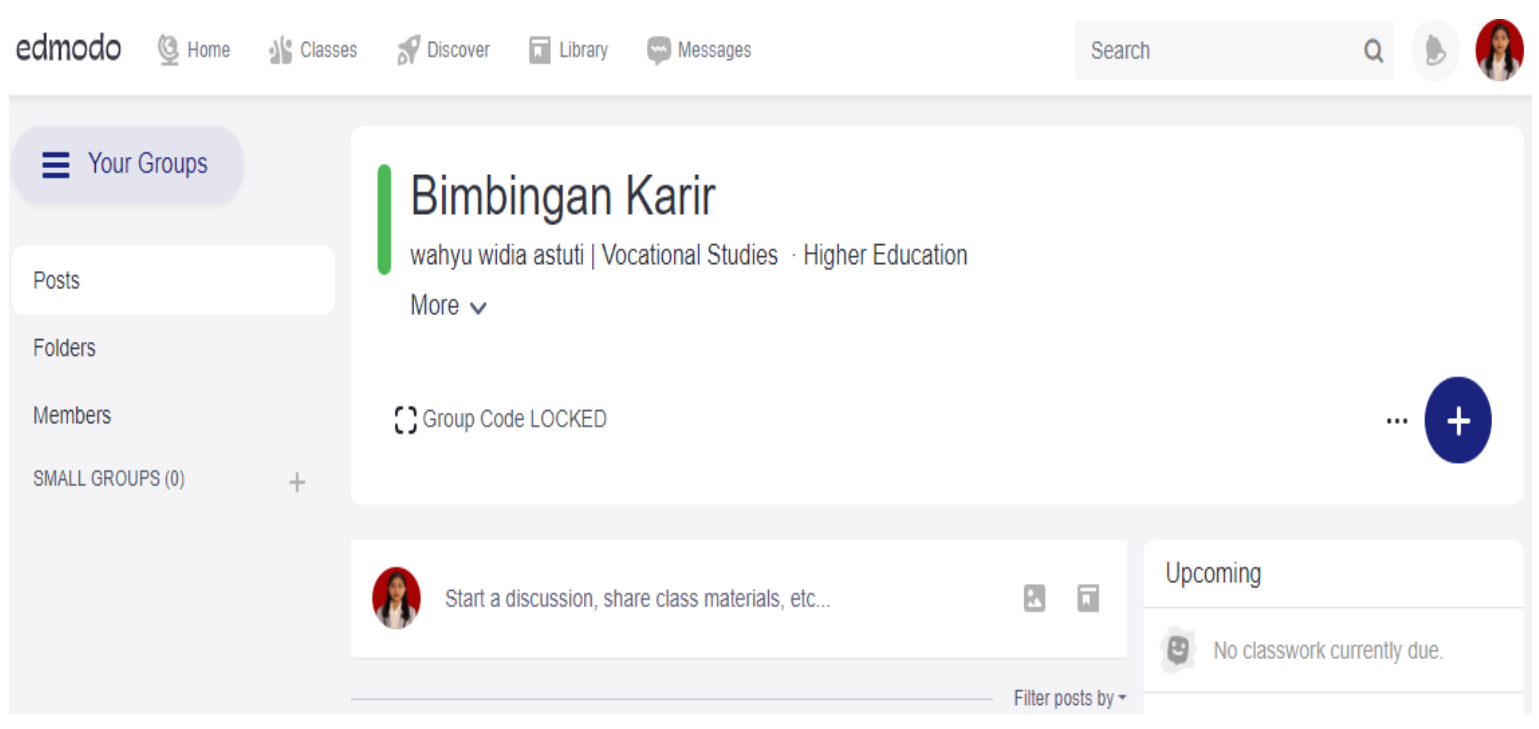

Gambar 5. Halaman Small Group

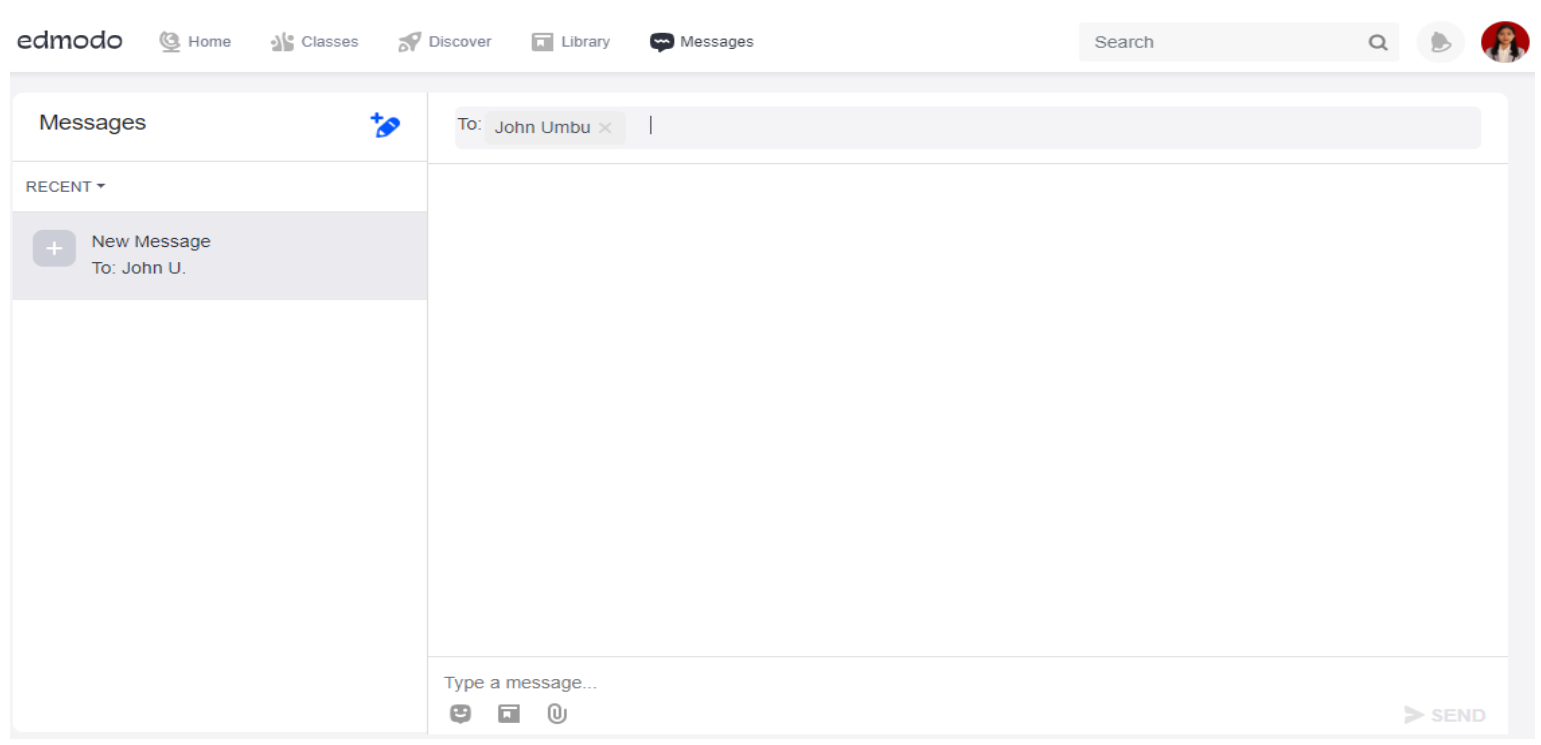

Gambar 6. Halaman Message

Tabel 1. Penilaian Ahli IT terhadap Media Aplikasi Edmodo

\begin{tabular}{clcc}
\hline \multirow{2}{*}{ No. } & \multirow{2}{*}{ Aspek yang Dinilai } & \multicolumn{2}{c}{ Validator } \\
\cline { 3 - 4 } & Tampilan & Dr. Mawardi, M.Pd & Dr. Ade Iriani, M.Si \\
\hline 1 & Akses & $85 \%$ & $85 \%$ \\
3 & Interaksi & $98 \%$ & $88 \%$ \\
4 & Desain Materi Layanan & $86 \%$ & $98 \%$ \\
5 & Kontrol & $80 \%$ & $86 \%$ \\
& Rata-Rata & $86 \%$ & $87 \%$ \\
& Rata-Rata 2 Ahli & & $89 \%$ \\
\hline
\end{tabular}

Tabel 1 juga memberikan informasi bahwa persentase penilaian ahli IT untuk menilai media yang digunakan, yaitu aplikasi Edmodo, untuk bimbingan karir dari dua ahli dengan lima aspek yang dinilai, sebesar $88 \%$. Berdasarkan kategori dan kriteria uji ahli, data angka persentase ini menunjukkan bahwa hasil penilaian ahli berada pada kategori baik sekali. 
Tabel 2. Penilaian Ahli Materi Bimbingan Karir untuk SMK

\begin{tabular}{clcc}
\hline \multirow{2}{*}{ No. } & \multirow{2}{*}{ Aspek yang Dinilai } & \multicolumn{2}{c}{ Validator } \\
\cline { 3 - 4 } & Visible & Prof. J.T. Lobby Loekmono, P.hD & Setyorini, M.Pd \\
\hline 1 & Interesting & $90 \%$ & $100 \%$ \\
2 & Simple & $80 \%$ & $80 \%$ \\
3 & Useful & $80 \%$ & $80 \%$ \\
4 & Accurate & $90 \%$ & $80 \%$ \\
5 & Legitimate & $80 \%$ & $70 \%$ \\
6 & Structure & $80 \%$ & $80 \%$ \\
7 & Rata-Rata & $84 \%$ & $100 \%$ \\
\multicolumn{2}{l}{} \\
\cline { 2 - 3 }
\end{tabular}

Tabel 2 memberikan informasi bahwa persentase penilaian ahli materi untuk menilai materi yang digunakan untuk bimbingan karir SMK dari dua ahli dengan tujuh aspek terhadap 15 butir pernyataan yang dinilai sebesar $84 \%$. Berdasarkan kategori dan kriteria uji ahli, data angka persentase ini menunjukkan bahwa hasil penilaian ahli berada pada kategori baik. Tabel 3 memperlihatkan bahwa rata-rata yang diperoleh dari hasil validasi uji coba lapangan model manajemen bimbingan karir menggunakan aplikasi Edmodo adalah 83\%, dengan lima aspek yang dinilai terhadap 28 butir pernyataan masuk dalam kategori baik.

Tabel 3. Penilaian Ahli IT terhadap Penggunaan Aplikasi Edmodo pada Bimbingan Karir

\begin{tabular}{llc}
\hline \multirow{2}{*}{ No. } & \multicolumn{1}{c}{ Validator } \\
\cline { 2 - 3 } & \multicolumn{1}{c}{ Aspek yang Dinilai } & Praktisi \\
\hline 1 & Tampilan & $83 \%$ \\
2 & Akses & $85 \%$ \\
3 & Interaksi & $81 \%$ \\
4 & Desain Materi Layanan & $88 \%$ \\
5 & Kontrol & $85 \%$ \\
& Rata-Rata Keseluruhan & $88 \%$ \\
\hline
\end{tabular}

Hasil analisis menggunakan persentase menunjukkan bahwa model manajemen bimbingan karir menggunakan aplikasi Edmodo berdasarkan uji ahli materi sebesar $88 \%$, uji ahli IT sebesar $84 \%$, serta uji praktisi dengan rata-rata $83 \%$, yang berarti berada pada kategori baik dan layak digunakan oleh praktisi lain untuk memberikan bimbingan karir menggunakan aplikasi Edmodo. Setelah hasil diperoleh, peneliti melakukan revisi produk berdasarkan masukan dari para ahli sebelum model ini diuji cobakan di lapangan untuk para calon pengguna, sampai pada akhirnya diperoleh hasil dan dinyatakan layak untuk digunakan dalam proses layanan bimbingan karir di SMK.

Peran guru Bimbingan dan Konseling dalam memberikan informasi karir sangat diperlukan oleh siswa (Adebowale, 2014), oleh sebab itu, untuk mencari solusi terhadap keterbatasan waktu guru BK bertatap muka, guru BK dapat memanfaatkan media yang ada, salah satunya adalah aplikasi (Puspitasari \& Nilandiny, 2016). Media lain yang bisa digunakan sebagai alternatif juga berupa web untuk membantu siswa memperluas informasi karir (Setyawan \& Wibowo, 2016) dan masih banyak media lain yang bisa digunakan, seperti aplikasi Edmodo yang peneliti gunakan untuk proses pelaksanaan bimbingan karir untuk SMK. Hal ini sejalan dengan penelitian Risqiyain dan Purwanta (2019) yang melakukan pengembangan media berupa multimedia untuk informasi karir yang secara efektif dapat meningkatkan kematangan karir siswa SMK. Saat ini, kemampuan berteknologi sangatlah dibutuhkan untuk dapat mengikuti perkembangan zaman yang sudah banyak menggunakan kelas online untuk proses pembelajaran. Sangat memungkinkan jika layanan bimbingan karir juga dilakukan secara online melihat banyaknya perubahan yang terjadi dalam proses pemberian layanan BK karir saat ini. Bimbingan karir secara online ini juga membantu siswa untuk menambah informasi karir lebih luas lagi. Hal ini sejalan dengan penelitian yang dilakukan oleh Murdiyanto et al. (2017) yang menggunakan blog untuk meningkatkan eksplorasi karir siswa lebih luas lagi tanpa terbatas waktu dan tempat. 
Selain peran guru BK, program bimbingan karir yang disusun oleh guru BK juga mempengaruhi kejelasan arah atau tujuan karir siswa, sehingga perlu mempertimbangkan aspek strength, weakness, opportunity, threat (SWOT) agar pelaksanaan bimbingan dan konseling karir menjadi bermutu dan sustainable (Jarkawi et al., 2017). Perlu juga menjadi pertimbangan untuk guru BK, ketika permasalahan yang dihadapi serupa dengan SMK Diponegoro dan SMK Kristen BM Salatiga, sehingga diharapkan guru BK mampu mencari alternatif untuk tetap melaksanakan program bimbingan karir dengan baik. Kelemahan dan kelebihan yang ada dapat menjadi dasar pembuatan program layanan BK berikutnya agar dapat berjalan lebih maksimal. Seperti yang telah diketahui, tingkat pendidikan Sekolah Menengah Kejuruan (SMK) memiliki tujuan khusus dalam pelaksanaan layanan bimbingan karir, yaitu mempersiapkan siswa/konseli untuk dapat menyesuaikan diri di masyarakat setelah tamat dari sekolah dan memiliki keterampilan bekerja yang dapat dipilih sesuai dengan minat, kemampuan, serta kebutuhan yang ada dalam lingkungan masyarakatnya (Permatasari, 2019 , p. 4). Hal ini sejalan dengan tujuan sekolah kejuruan, yaitu menghasilkan siswa/konseli yang mampu dan siap kerja di tengah-tengah masyarakat, sesuai dengan kompetensi perilaku sikap dan kerja dalam bidang kejuruan yang ditempuhnya, sehingga siswa/konseli tersebut benar-benar mampu bekerja secara produktif sesuai harapan dan syarat yang diinginkan oleh dunia usaha dan dunia industri (DUDI) serta peka akan kebutuhan jasa/industri yang diperlukan oleh masyarakat saat ini (Permatasari, 2016, p. 270), sehingga sangat diperlukan analisis yang tepat untuk dapat membuat program yang sesuai dengan kebutuhan siswa di SMK Diponegoro dan SMK Kristen BM Salatiga, mengacu pada keterbatasan waktu, rasio guru dan siswa yang tidak seimbang karena kurangnya guru BK.

Beberapa SMK saat ini sudah tidak memiliki jam mengajar untuk guru BK, sehingga waktu untuk bertatap muka dan mendapat bimbingan karir juga sangat terbatas. Namun hal ini tidak mengurangi kewajiban guru dalam menjalankan perannya di sekolah, seperti yang dilakukan Irwan et al. (2017) yang merancang sebuah software untuk proses bimbingan karir dengan pertimbangan bahwa peserta didik tetap bisa mendapat layanan bimbingan karir dan tetap dapat konsultasi tanpa harus tatap muka guna memberikan informasi karir yang luas untuk siswa SMK. Pentingnya pendidikan di sekolah sebagai landasan pengambilan keputusan siswa menegaskan pentingnya memberikan perhatian pada perkembangan karir siswa (Nursalim, 2015, p. 81), sehingga, guru BK saat ini harus bisa memilih alternatif paling tepat yang dapat digunakan untuk memberikan bimbingan karir untuk menjawab masalah keterbatasan waktu dan kurangnya sumber daya manusia (SDM) dalam pelaksanaan BK di sekolah. Teknologi saat ini sudah sangat canggih, banyak sekali media pembelajaran online yang bahkan bisa digunakan untuk pemberian layanan bimbingan karir, salah satunya aplikasi Edmodo yang bisa diaplikasikan dengan smartphone. Permasalahan yang sama dengan penelitian tersebut juga terjadi di SMK Diponegoro dan SMK Kristen BM Salatiga, di mana guru BK terkendala dengan pertemuan tatap muka yang sangat terbatas, sehingga, bimbingan karir saat ini dilaksanakan dengan fasilitas, SDM, dan waktu yang kurang mendukung proses pemberian layanan.

Perlunya informasi karir yang luas untuk SMK membuat guru BK harus memikirkan cara agar siswa dapat mengeksporasi karir dengan maksimal. Eksporasi karir, yang merupakan sebuah perilaku pemerolehan informasi yang berujung pada terbentuknya kematangan karir seseorang, membuat guru BK mempunyai tanggung jawab untuk menyediakan informasi yang luas terkait kompetensi serta lapangan pekerjaan yang tersedia bagi para siswa (Haq \& Farida, 2019). Untuk menjadi lebih maksimal lagi, maka dibuatlah satu model bimbingan karir menggunakan aplikasi, seperti penelitian yang dilakukan oleh Nisa dan Wiryosutomo (2018), yang membuat model berupa aplikasi karir menggunakan model teori Cognitive Information Processing (CIP) yang membantu peserta didik dalam membuat keputusan karir dan pelaksanaan karir yang lebih maksimal.

Beberapa hasil penelitian juga menunjukkan bahwa bimbingan karir secara online sangat membantu guru BK untuk memberikan informasi yang diperlukan peserta didik. Hal tersebut sejalan dengan penelitian yang dilakukan oleh Puspitasari dan Nilandiny (2016) yang menggunakan web untuk perencanaan karir di SMK yang berangkat dari masalah aktivitas perencanaan karir tidak berjalan dengan maksimal dikarenakan keterbatasan waktu, tempat, dan SDM, sehingga, permasalahan tersebut dapat diatasi dengan dibangunnya sebuah aplikasi secara online yang dapat membantu pihak guru BK untuk melakukan aktivitas, antara lain proses konsultasi antara siswa dan 
guru BK melalui fitur pesan, informasi lowongan kerja di mana masalah itu juga dihadapi oleh SMK Diponegoro dan SMK Kristen BM Salatiga saat ini. Selain itu, kemajuan yang pesat dalam teknologi membuat perubahan pada proses pengajaran yang dilakukan oleh guru (Zaman \& Jabar, 2020). Maka dari itu, peneliti menggunakan aplikasi Edmodo sebagai media yang digunakan dalam proses pelaksanaan karir. Penggunaan aplikasi ini membantu guru untuk memberikan info dan melaksanakan diskusi secara klasikal, grup, dan juga individu. Model yang dirancang oleh peneiti ini diberi nama model MBK-MAE.

Hasil dari uji ahli dan uji materi menyatakan bahwa model MBK-MAE ini layak digunakan untuk proses bimbingan karir. Pada aspek interaksi, diperoleh persentase paling tinggi yang menunjukkan bahwa aplikasi ini mampu memberi fasilitas interaksi yang memadai untuk proses bimbingan. Hasil penelitian ini dilengkapi dengan hasil uji coba lapangan terbatas oleh para praktisi (calon pengguna), yang menunjukkan bahwa model manajemen bimbingan karir menggunakan aplikasi Edmodo layak digunakan agar pemahaman akan informasi karir yang diperoleh dapat digunakan sebagai bahan acuan dalam mengembangkan cita-cita pada pengambilan keputusan karir (Hidayati, 2015; Muttaqin et al., 2017). Para praktisi juga memberi nilai tinggi untuk desain materi layanan yang sudah ada di dalam aplikasi yang dirancang oleh peneiti untuk bisa menjadi acuan guru BK di sekolah dalam menyiapkan layanan menggunakan media yang memadai, karena salah satu faktor yang dapat mempengaruhi keberhasilan proses layanan BK adalah dengan penggunaan media (Ampa, 2015). Dengan adanya model MBK-MAE ini, diharapkan guru BK dapat lebih maksimal dalam memberikan layanan bimbingan karir kepada siswa.

\section{SIMPULAN}

Pelaksanaan bimbingan karir yang saat ini kurang maksimal dikarenakan adanaya perubahan kurikulum yang mengakibatkan kebingungan bagi beberapa sekolah, yang pada akhirnya memutuskan untuk tidak memberikan jam mengajar untuk guru BK. Tidak adanya jadwal masuk kelas menyebabkan guru BK mengalami kesulitan dalam memberikan layanan BK, termasuk layanan bimbingan karir. Meskipun demikian, guru BK tetap berusaha memberikan layanan bimbingan karir dengan maksimal, salah satunya dengan mencari alternatif paling tepat untuk tetap bisa memberikan bimbingan karir sesuai kebutuhan siswa. Keterbatasan waktu dan rasio guru BK yang tidak seimbang menjadi masalah utama yang membuat peneliti mengembangkan sebuah model manajemen bimbingan karir menggunakan aplikasi Edmodo yang diberi nama MBK-MAE. Model terdiri dari gambar model dan deskripsinya, program layanan bimbingan karir dengan menggunakan aplikasi Edmodo, panduan guru, panduan siswa, dan panduan operator IT. Model yang dirancang peneliti mendapatkan penilaian yang baik setelah melewati uji ahli dan uji coba lapangan terbatas yang kemudian dinyatakan layak untuk digunakan. Model ini diharapkan dapat membantu guru BK dalam proses pelaksanaan bimbingan karir dan kepala sekolah serta semua warga sekolah mendukung penuh dengan memberikan fasilitas dan bantuan yang diperlukan oleh guru BK. Untuk keefektifan model, pada penelitian selanjutnya dapat dilakukan uji coba lapangan luas, sehingga model MBK-MAE dapat digunakan lebih luas lagi.

\section{DAFTAR PUSTAKA}

Adebowale, O. (2014). Career information processing strategies of secondary school student in Osun State (Nigeria). Inkanyiso: Journal of Humanities and Socila Sciences, 6(1), 66-76. $\begin{array}{llll}\text { Retrieved on } & \text { September }\end{array}$ https://www.ajol.info/index.php/ijhss/article/view/105749

Ampa, A. T. (2015). The implementation of interactive multimedia learning materials in teaching listening skills. English Language Teaching, 8(12), 56-62. https://doi.org/10.5539/elt.v8n12p56

Arikunto, S. (2011). Prosedur penelitian: Suatu pendekatan praktik. Rineka Cipta.

Gall, M. D., Gall, J. P., \& Borg, W. R. (2003). Educational research: An introduction. Pearson Education. 
Haq, A. H. B., \& Farida, R. (2019) Orientasi karir pada siswa SMP: Pilihan jurusan dan gambaran pekerjaan di masa depan. Psikostudia: Jurnal Psikologi, 8(1), 7-14. https://doi.org/10.30872/psikostudia.v8i1.2334

Hidayati, R. (2015). Layanan informasi karir membantu peserta didik dalam meningkatkan pemahaman karir. Jurnal Konseling Gusjigang, 1(1). Retrieved on May 2019 from https://jurnal.umk.ac.id/index.php/gusjigang/article/view/258

Irwan, I., Gustientiedina, G., Sunarti, S., \& Desnelita, Y. (2017). Counseling model application: A student career development guidance for decision maker and consultation. IOP Conference Series: Earth and Environmental Science - International Conference on Environment and Technology (IC-Tech). https://doi.org/10.1088/1755-1315/97/1/012045

Jarkawi, J., Ridhani, A. R., \& Susanto, D. (2017). Strategi bimbingan dan konseling karir bermutu pada Sekolah Menengah Kejuruan Syuhada Banjarmasin. Jurnal Kajian Bimbingan dan Konseling, 2(3), 123-131. https://doi.org/10.17977/um001v2i32017p123

Murdiyanto, A., Purwanta, E., \& Kamaruddin, K. (2017). Pengembangan layanan informasi karier berbasis media blog untuk meningkatkan eksplorasi karier siswa di SMP Kota Magelang. JBKI: Jurnal Bimbingan Konseling Indonesia, 2(2), 40-46. http://dx.doi.org/10.26737/jbki.v2i2.255

Muttaqin, R., Wagimin, W., \& Tadjri, I. (2017). Keefektifan layanan informasi karier berbantuan video interaktif dan live modeling untuk meningkatkan pemahaman karier siswa SMP. Jurnal Bimbingan Konseling, 6(2), 174-179. Retrieved from https://journal.unnes.ac.id/sju/index.php/jubk/article/view/21794

Nisa, E. Z., \& Wiryosutomo, H. W. (2018). pengembangan aplikasi karir model Cognitive Information Processing (CIP) untuk perencanaan studi lanjut siswa kelas IX SMP Negeri 1 Panceng Gresik. Jurnal Bimbingan dan Konseling UNESA, 8(2), 337-344. Retrieved on February 2020 from https://jurnalmahasiswa.unesa.ac.id/index.php/jurnal-bkunesa/article/view/24585

Nursalim, M. (2015). Pengembangan profesi bimbingan dan konseling. Erlangga.

Peraturan Menteri Pendidikan dan Kebudayaan Nomor 81A Lampiran IV Tahun 2013 tentang Implementasi Kurikulum. (2013).

Peraturan Menteri Pendidikan Nasional Nomor 27 Tahun 2008 tentang Standar Akademik dan Kompetensi Konselor. (2008).

Permatasari, N. (2016). Evaluasi program layanan bimbingan karir di SMK negeri se-Kota Banjarmasin. Disertasi, Program Pascasarjana Universitas Negeri Jakarta, Jakarta.

Permatasari, N. (2019). Layanan bimbingan karir di Sekolah Menengah Kejuruan (SMK). CV IRDH.

Puspitasari, W., \& Nilandiny, R. (2016). Membangun aplikasi perencanaan karir online berbasis web dengan menggunakan metode Waterfall (Studi kasus pada SMK X). Jurnal Rekayasa Sistem \& Industri, 3(2), 9-17. Retrieved on January 2020 from https://doi.org/10.25124/jrsi.v3i02.26

Risqiyain, L. H., \& Purwanta, E. (2019). Pengembangan multimedia interaktif informasi karir untuk meningkatkan kematangan karir siswa Sekolah Menengah Kejuruan. Jurnal Kajian Bimbingan dan Konseling, 4(3), 88-93. https://doi.org/10.17977/um001v4i32019p088

Setyawan, I., \& Wibowo, M. E. (2016). Pengembangan model layanan informasi karir berbantuan web tentang studi lanjut ke perguruan tinggi. Jurnal Bimbingan Konseling, 5(1), 29-36. Retrieved from https://journal.unnes.ac.id/sju/index.php/jubk/article/view/18510

Sukmadinata, N. S. (2012). Metode penelitian pendidikan. PT Remaja Rosdarya. 
74 - Jurnal Akuntabilitas Manajemen Pendidikan

Undang-Undang Republik Indonesia Nomor 20 Tahun 2003 tentang Sistem Pendidikan Nasional. (2003).

Winkel, W. S., \& Hastuti, S. (2012). Bimbingan dan konseling di institusi pendidikan. Media Abadi.

Zaman, F. F., \& Jabar, C. S. A. (2020). Pelaksanaan program Edmodo di sekolah dasar. Jurnal Akuntabilitas Manajemen

Pendidikan,

$8(1)$

96-107. https://doi.org/10.21831/jamp.v8i1.30589 